\title{
HEALTH EDUCATION POLICY 1916-1926: VENEREAL DISEASE AND THE PROPHYLAXIS DILEMMA
}

\author{
by
}

\author{
BRIDGET A. TOWERS*
}

\begin{abstract}
THIS PAPER seeks to account for the development of a public health education policy with respect to venereal disease during the period 1916-1926. Two competing pressure groups, the National Council for Combatting Venereal Disease and the Society for the Prevention of Venereal Disease, defended opposing programmes; the one based on moral education (NCCVD) and the other (SPVD) on medical prophylaxis. Many of the interests represented by the groups and the political dimensions that they took, were influenced by factors only very tangentially connected to health education.

Any account of the development of policy in this field needs placing in the context of the early history of nineteenth-century anti-vice crusades; the role of the Army Medical Corps during the 1914-18 war; and the bureaucratic protectionism of the Ministry of Health personnel.
\end{abstract}

\section{PRESSURE GROUPS IN THE POLICY PROCESS}

Health education has occupied a singularly marginal position in the development of British health policy; with dreary regularity it has been proclaimed as an essential part of all health programmes but seldom has this seemingly ritual recognition been reflected in any coherent long-term policy let alone any significant organizational framework. Instead health education, despite its endorsement by most sections of the medical marketplace, has been left to a variety of competing agencies. The government preferred to act as a discreet broker in advising local authorities which of these agencies had "preferred" status and also providing, with similar discretion, funds to these agencies. This brokerage role was consolidated by the recognition in 1948 of a central co-ordinating council responsible for health education when limited funds were guaranteed on a regular basis through local authority financing.

The early history of the development of health education has traditionally been portrayed as a long and united crusade, an interpretation that "official" histories have also upheld.' However the evidence available indicates that this history could be read more accurately as a record of fierce competition between organizations with

* Bridget A. Towers, D. Crim., School of. Sociology, Kingston Polytechnic, Kingston-upon-Thames, KT1 2EE, Thanks are due to the 'Health Education Research Group', Dr. J. R. East, and Ms. W. Moreton for all their help and advice on this paper which forms a part of the group's Research project.

1 Sir A. Daltry, 'Central Council for Health Education 1927-52', Health Education Journal, 1959, 17. 


\section{Venereal disease and the prophylaxis dilemma 1916-1926}

conflicting programmes and policies. The government through the Local Government Board and later through the Ministry of Health played an active role in sponsoring and endorsing certain policies and organizations but it avoided at the same time any radical policy, programme, or issue which might, in their view, be politically contentious. This inevitably meant that no positive health education policy was developed, rather only an abundance of rhetoric. It also meant that those agencies which did receive support tailored their programmes to safeguard their revenue, similarly those bidding for support had little success if they developed programmes which challenged the existing administrative framework or the prevailing consensus on health care.

In the Political Science field there is a considerable body of literature on the influence of pressure groups on policy-making in Britain, both historically and contemporarily. One debate revolves around the contention that modern liberal democracies have evolved a policy-making process which allows for the maximum expression of a wide range of interests through competing pressure groups. This is contested by opposing views which maintain that the style of pressure group politics specifically favours those interests and persons which are already well placed within the society's power structure; hence pressure groups represent a competition of only already dominant and powerful interests. ${ }^{2}$ The extent to which governments are able to balance these powerful interest groups against each other or by the withdrawal of patronage and funds is much debated and documented. ${ }^{3}$ The case being considered here supports the view that competing pressure groups are not necessarily given the same legitimation, or access to decision-makers. The barriers that prevent access of one group and facilitate the influence of another are discrete and not readily acknowledged by the administrators, particularly when negotiations and interactions between the groups and the administration are kept private and informal and are removed from public accountability and scrutiny.

In this case although two particular organized groups are the main focus of the study, there were nevertheless many other interests involved in the conflict between them, and therefore this account strays outside of the conventional area of pressure group studies. This is necessary in order to locate this particular dispute in the context of the emerging health service.

This aspect of health care cannot be excluded from the general monopolizing strategies of the medical profession. Doctors played a significant part both directly in the voluntary bodies and indirectly through their sponsorship of them; they also exercized a powerful influence through their position on significant consultancy committees and directly through their spokesmen in the Ministry. Many of these apparently "lay" voluntary organizations were in fact stalking horses of the medical profession and the composition of their executive committees reflect this.

A conventional pressure group model also has limitations in so far as it would tend to exclude many of the unstructured activities and programmes of early health campaigning societies. Their membership was often changeable, and probably

2 B. Guy Peters, 'Insiders and outsiders, the politics of pressure group influence on bureaucracy', Administration and Society, 1977, 9: no. 2.

3 Ibid. 


\section{Bridget A. Towers}

dependent more upon notions of fashion rather than upon differences in policy. The mode of early organization and propaganda campaigns was characteristic of a crusade concerned with stimulating a mass following behind a moral theme of "hygiene". 4

Finally, any analysis in terms of pressure group politics would in this particular case need supplementing with an account of the role played by government agencies and personnel in directly influencing the programmes and politics of certain groups. This role varied from involvement through discreet and informal meetings to rather more direct methods of cutting off funds and withdrawing co-operation. There is considerable evidence to suggest that Whitehall protectionism influenced the programmes of health education groups. This area of departmental and administrative politics is a web of conflicting interests, and in accounting for the early history of health education this aspect of the policy process would need to be closely examined.

One particular issue which provided a focus for the conflict of interests of health education groups, doctors, the military, government, and the church was that of "prophylaxis". 5 It has featured in health education on many occasions, in the early days of this century it appeared in the venereal disease propaganda; more recently it was to be found in the birth control campaigns of this decade. It has often been contended that moral arguments have predominated in health education, and that non-medical personnel by their involvement have trivialized and devalued this part of health care. The implication of this argument is that by excluding the medical profession from control in this sector of health care, health education has been rendered ineffective. 6

This paper deals with the interests and conflicts involved in the development of public health education. The view that this rested on a struggle between moralists and medics is rejected; instead a rather more complicated pattern is proposed which features overlapping interest groups, professional monopolising, secular crusading, and administrative politics.

\section{THE ABOLITIONIST CRUSADE}

Certainly the British crusaders for public hygiene never managed to organize themselves on such a large scale and with such effect as the American purity leagues, and the American anti-vice campaigns. By comparison they remained a divided collection of separate groups sponsoring diverse issues although they appeared to share a vague ideological commitment to the values of "moral and physical hygiene" particularly endorsing theories which linked the defence of Empire with the defence of Race. The active and not purely nominal leadership was dominated by upper middle class women, churchmen, and members of the peerage. It is easy to see why they have been a ready target for the criticism that they represented a reactionary outpost of class morality blocking the development of medical approaches to public health. However,

4 J. R. Gusfield, Symbolic crusade, Chicago, University of Illinois Press, 1969.

5 Prophylaxis literally means the preventive treatment of disease, but in this case it came to have a more specific meaning of methods that could be used (disinfectants - potassium permanganate, calomel, etc.) immediately after intercourse to ensure that infection did not occur. There are a few occasions when the sheath is also defined as a prophylactic measure against venereal disease. But it generally meant some form of immediate disinfection.

6 See, for instance, T. Rosebury, Microbes and morals, New York, Viking Press, 1971. 


\section{Venereal disease and the prophylaxis dilemma 1916-1926}

this view may well need modifying when the movement is seen in the context of the range of disputes that it engaged in with the military-medical establishment.

Beardsley, in his examination of the documents of the Imperial War Conference, July 1918, dealing with the policies of the allies towards venereal disease and prostitution, raises the military-medical dimension. ${ }^{7}$ The evidence suggests that the issue was considered to be of no mean importance by the Americans and Dominions and that they were appalled at the failure of the British to tackle the problem. Beardsley applauds the strong line taken by the Americans on venereal disease control which he attributes to the influence of the American anti-vice crusades, whilst he holds the National Council for Combatting Venereal Disease (NCCVD) responsible for the lethargy of the British: "High ranking clergymen and upper class moralists who took the lead in the anti-vice crusade downplayed the medical approach to venereal disease with the result that the clinics and prophylaxis never got the attention they did in the U.S.A." 8 There is however a far wider background to these differences in policy on venereal disease control, a background over which Beardsley quickly glosses with his remark that before 1916 there had been no public discussion of venereal disease in Britain. It seems likely that it is the very existence of a long period of public discussion, Royal Commissions, and protest movements which might account for the position taken by the British authorities on venereal diseases. There was, and still is, considerable debate as to the extent of venereal diseases in the population during this period. Official figures are extremely unreliable; a point acknowledged by the Royal Commission of 1916 in its conclusion that the rate of infection in the British military was approximately thirty per cent.

Legislation to control venereal disease in the armed forces was first passed in 1864 with the Contagious Diseases Acts. Although they were confined in their application to military and naval bases and their surrounding areas, they were aimed directly at the control of prostitution in the belief that regulating and inspecting prostitutes was the most effective method in controlling venereal disease itself; i.e., to control what was perceived of as the "source of infection". Prostitutes in military areas were subject to surveillance and arrest, compulsory examination and treatment, and even imprisonment or banishment from the area. The identification of prostitutes and the enforcement of the Acts was left to a morals policing system which at the local level provided ample scope for blackmail, corruption, and victimization. 9

A series of supplementary and extended Acts were passed in 1868 and 1869 and there was considerable enthusiasm in the Privy Council for extending them to cover the whole country. In fact the Foreign Office was commissioned to do a survey on venereal disease control. Sir John Simon (Medical Officer to the Privy Council) arranged for this extensive survey to be made. Requests were sent to all British ambassadors to submit reports on the policies of venereal disease control that were followed in their country of posting. Simon was of the opinion that such an extension to the Acts was

7 E. Beardsley, 'Allied against sin: American and British responses to venereal disease in World War I', Med. Hist., 1976, 20: 189-202.

8 Ibid.

9 A study of these Acts and their implementation is given by B.-J. Walkowitz, 'We are not beasts of the field', Feminist Studies, summer 1973. 


\section{Bridget A. Towers}

only possible if the Bill was well drafted and based on an impressive collection of data. ${ }^{10}$ However opposition was becoming more vocal and the Royal Commission of 1870 came out in favour of a reduction in the powers of routine detention and inspection whilst at the same time allowing the Acts to remain on the statute books.

Those opposing the Acts, known as the Abolitionists, incorporated a wide range of interest groups, most strongly featured among them was Josephine Butler's National Association, a campaign against "State regulated vice". Josephine Butler saw the Abolitionist movement as founded upon a range of propositions which allowed it to have a broad-based appeal. The eight-point protest which was first published in the Daily News 1 January 1870, (endorsed, among others, by Florence Nightingale, Harriet Martineau, and Mary Carpenter) held that: (1) There had been no proper discussion of the Acts in the press or in Parliament. (2) For women they removed every guarantee of personal security since they put their reputation, freedom, and person absolutely in the power of the police. (3) The law should define clearly any offence which it sought to punish and this it failed to do. (4) It was unjust to punish the sex who were the victims of vice and leave unpunished the sex who were the main cause. (5) The path to evil was made more easy. (6) The measures violated the feelings of women whose sense of shame was not wholly lost, and further brutalized those who were most abandoned. (7) The disease would never be removed by legislation. (8) The conditions of the disease were moral not physical.

A programme of press campaigns, public meetings, lobbying at elections in marginal constituencies, and international tours ensured considerable support for the Abolitionists, and although they failed to get the Acts repealed until 1886, they had by 1880 made them inoperable by securing vitiating administrative changes in their application. ${ }^{11}$

The Abolitionist crusade embraced a considerable range of beliefs and attitudes towards venereal disease, its control and the role of government in devising public health programmes. Many of the attitudes were clear examples of Victorian moral selectivity; they chose to ignore institutional cruelty and violence but focused instead on personal sexual morality. They refused to accept the possibility that so-called "vice" was often the only means of securing clean living conditions, good food, and good clothing. ${ }^{12}$ At the same time they invoked their same class morality to condemn the medical profession: "The purification of the medical profession was hoped for and the exposure and defeat of those deadly materialist doctrines . . . which together with the dogmatism and despotism of certain doctors has begun to exercise so fatal an influence over our legislative councils." 13

The definition of the crusade as a woman's issue was also a significant feature in recruitment; even if in later years Josephine Butler tended to play down this aspect. Certainly Victor Hugo characterized the movement as a sexist struggle, wherein "laws are made by men to tyrannise over women". 14 Josephine Butler's feminism was more

$10 \mathrm{~J}$. B. Post, 'A Foreign Office survey of venereal disease and prostitution control 1869-1870', Med. Hist. , 1978, 22: 327-334.

11 Josephine Butler, Personal reminiscences of a great crusade, new ed., London, H. Marshall, 1910.

12 R. Pearsall, The worm in the bud, London, Pelican Books, 1971.

13 Butler, op. cit., note 11 above.

14 Ibid. 
oblique, she was more impressed with the way in which upper middle class women had become involved in an issue "which led them to work actively on behalf of their less fortunate sisters", it was on these grounds of philanthropy that she championed the solidarity of the women of the country. 15 The focus on the civil liberties aspect of the legislation was always paramount and provided for some strident attacks on policing in general; it was a characteristic stance of the upper middle classes to oppose state policing schemes which they saw as a form of continental tyranny. Josephine Butler indulges this feeling in a vitriolic description of her meeting with Lecour, Head of the Paris morals police: "His countenance is to me repulsive, he has a fixed smile that of the hypocrite, he is a shallow actor, an acrobat, a stage manager . . . intoxicated with the sense of power." 16

In accounting for the final repeal of the Acts it is most likely that the main arguments were that the legislation was simply inoperable due to both the failure of magistrates to convict and the police to prosecute. The Abolitionists were instrumental in making the debate public and exhibiting the government as responsible for immoral legislation. ${ }^{17}$ Interpretations of the Abolitionist crusade have varied from that of an early feminist movement to one of cynical self-interest.

In his study of the Child Saving Movement in Illinois, U.S.A., Platt identifies a similarly contradictory motivation: "The assumption that women were morally purer than men, better capable of altruism and self sacrifice, was the core of the myth of domesticity against which the feminists were in revolt . . . feminist and antifeminist assumptions seemed curiously to coincide . . ."18 There is evidence of a continuity of this crusade through to the 1930s in the campaign against the popularly called "white slave trade", an issue more accurately described by the League of Nations as one of the international traffic in prostitution. 19 What is clear is that the programme of opposition was a broad one and that wide support was gained precisely because of this; so that to characterize the Abolitionists as moving purely on the moral issue of sexual promiscuity is to ignore a wide section of its activities. It is this history of the early attempts to deal with venereal disease which Beardsley ignores and so enables him to make an unhappy comparison between the British and American policies.

\section{MILITARY RESPONSES TO V.D.}

Beardsley characterizes the American anti-vice crusades as being primarily a "mass interest seeking an outlet for heightened nationalism", 20 although as a movement it probably had its roots in earlier morality campaigns. He clearly identifies its activities during the 1914-18 war as being closely linked with the military and the legislature. Whilst on the one hand campaigning vigorously for the abolition of all regulated brothels, they nevertheless defended fiercely the other aspects of the Regulationist policies - namely the forced imprisonment and treatment of all prostitutes or women

15 Ibid.

16 Ibid.

17 An account of a comparable regulationist policy and the abolitionist opposition in Germany is given by: R. J. Evans, 'Prostitution, state and society in Imperial Germany', Past and Present, February 1976, no. 70.

18 A. Platt, 'The child savers', Annals of the American Academy, January 1969, no. 381, pp. 21-38.

19 Proceedings of Imperial Social Hygiene Congress, 1929.

20 Beardsley, op. cit., note 7 above. 
suspected of having venereal disease. American Purity Leagues operated local vigilante groups, either hustling suspected women out of town or intimidating and reporting them. These activities were backed up by legislation in many states coming from the public health departments. According to Beardsley, the Illinois Board of Public Health "had power to hospitalise any woman thought to be infected and if she refused then the Board posted a large placard on her home reading 'suspected V.D.' "21 The U.S. army also reflected this medical policy in its regulations that any soldier who failed to take treatment for venereal disease could be courtmartialled and imprisoned, and went even further in making the use of prophylactic measures compulsory (sheaths and disinfectants). It was this strong line taken by the Americans which was so vigorously defended at the Imperial War conference.

The British approach to the control of venereal disease among the troops was the Defence of the Realm Act No. 40D.22 These measures were considered derisory by the Americans and Canadians, who protested that the British were failing to take the matter seriously and were too strongly influenced by moralist groups who refused to sanction the use of medical treatments. The Defence of the Realm Act (40D) provoked a considerable amount of domestic opposition, and arguments from the old Abolitionist crusade were rehearsed again. The Cabinet was not minded to introduce dissent at a time when it was promoting blind patriotic support of the military. Haig wrote to the Secretary of War, also opposed to any Regulationist policies, which he saw as an indication of trivial concern with fornication in the army. 23

Whilst the generals in the British army may have taken a laissez-faire approach to venereal disease or even a pragmatic tolerance of regulated brothels, the medical corps in the army took a strong line of attack on the government for its failure to develop a treatment and prevention programme. They saw the issue as one of medical and military importance and enthusiastically supported the American policies; they were also similarly dismissive of the NCCVD which they accused of "hedging between deference to sentiment and the raison d'etre of their existence - namely controlling V.D."24 In a paper read to the Royal Institute of Public Health, Colonel Adami (surgeon to the Canadian forces) outlined the medical-military response to venereal disease as he saw it: the compulsory inspection and treatment of all prostitutes, compulsory treatment of all those infected, emergency treatment centres in all city centres, record sheets to be kept of all infected persons, military personnel to be docked half-pay if infected, and commanders to be dismissed if the rates of infection in troops under their command rose beyond certain levels, the establishment of special hospitals, mobile clinics, and the provision of prophylactic "packets" to all troops to disinfect themselves after sexual intercourse. 25

21 Ibid.

22 Defence of the Realm Act, Section (40D), March 1918 held that: "No woman who is suffering from V.D. in a communicable form shall have sexual intercourse with any member of the armed forces or any of H.M. allies, or solicit or invite any member to have sexual intercourse with her. A woman charged with an offence under this regulation shall if so be required be remanded for not less than a week for medical examination as a summary offence."

23 Beardsley, op. cit., note 7 above.

24 Letter from Senior Surgeon Charles P. Child to Br. med. J., 1919, ii: 797-798.

25 J. G. Adami, 'The policy of the ostrich', ibid., 1919, i: 98-101. 
The army was primarily concerned about the wastage of manpower that occurred as a result of venereal disease infection. They wanted to sustain their divisions in the field at the highest numerical strength and they were therefore loath to have soldiers absent for long periods being treated back at base. This led to the development in the British army of short intensive treatments with salvarsan and mercury, often resulting in serious and unpleasant side-effects, ranging from convulsions to jaundice. 26 The American expeditionary forces took this one stage further and administered treatments at the front line by urologists attached to the units; they even developed special venereal labour companies for those undergoing treatments since they wanted to ensure that venereal disease was not made a convenient excuse to escape military duties. 27

What was apparent in the debates over policy on venereal disease was that the military were capable of introducing a programme of control that was simply not administratively or politically possible in the civilian population. The Americans on the other hand had secured strong civilian support through their anti-vice crusades which had totally subordinated all issues of civil rights to the medical-treatment ethic; in so doing they defended the extension of both police powers and public health controls. The British military was still dominated by a class leadership which defended the belief that army morale was contingent on sexual activity, they were therefore loath to allow civilian interference in shutting down brothels and were quite intolerant of any moral arguments on sexual promiscuity. However despite the attitude of their generals the British Army Medical Corps instituted practices of treatment and prevention which ensured the widespread adoption of a medical approach rather than one based on regulations of social control. It was in the army that self-administered disinfectants were first provided in Britain and it was this so-called "packet system" which was to become a central part of the debate in health education in the next decade.

The term "prophylactic packet" meant little more than an easily portable medication that could be used by the individual himself, the materials varied in composition from "Metchnikoff's Formula" based on calomel and carbolic acid to "Condy's Fluid" made up of potassium permanganate. ${ }^{28}$

What can be seen emerging at this time is the particular issue, i.e. the role of prophylaxis in the treatment of venereal disease as focused around the "packet system"; this became a contentious issue because it involved a variety of interest groups who were defending values and programmes which were often only tangentially connected with the prevention of venereal disease.

IV. THE EMERGENCE OF THE NATIONAL COUNCIL FOR COMBATTING VENEREAL DISEASE

The National Council for Combatting Venereal Disease (NCCVD) was founded as a direct outgrowth of the 1916 Royal Commission on Venereal Diseases; in fact the organization was expressly tailored to fit the pattern of the "independent society" that was recommended in the final report. ${ }^{29}$ Lord Sydenham as the chairman of the Royal

26 T. F. Ritchie, 'The treatment of venereal disease in armies', Int. J. publ. Hlth, 1921, 2: 61.

27 Ibid.

28 Ibid.

29 The inaugural meeting of the NCCVD was held 11 November 1914, but this was a provisional meeting 


\section{Bridget A. Towers}

Commission was invited to become president of the Council, and most of the members of the Commission also accepted the invitation to join. The NCCVD saw its role as "giving effect to the policies recommended in the Report and acting as an independent society capable of stimulating the powers that be ..."30 The report itself was surprisingly humdrum and avoided recommendations on any of the contentious issues of notification, detention, compulsory treatment, or prophylaxis; instead the general conclusions were that prevention should be anchored on a policy of widespread education and propaganda, and it was precisely in the control of this aspect of policy that the NCCVD saw its opportunity for development and government financing.

The Local Government Board issued its directives on new procedures for treating venereal disease to local authorities in July 1916 . They were mainly concerned with the provision of clinics and other out-patient facilities and with the prescription of salvarsan as medication; however a supplementary duty was also placed upon local authorities to educate the public in the causes and treatment of venereal diseases and generally to promote health habits. There was a provision that seventy-five per cent of the funds for these services would be provided by the Treasury. This system of financing was to prove extremely advantageous to the role of an independent organization like the NCCVD, since it meant that they merely had to negotiate with the medical committee of the Board of Local Government in order to secure for themselves an accredited status and a direct exchequer grant. If the financing of health education had been left to the local authorities, then individual bargaining arrangements and contracts would have had to be drawn up. It was an arrangement which also suited the Board; as Newsholme (Chief Medical Officer) noted in a minute to Long (President of the Local Government Board), the grants to the local authorities were preferable since they were only seventy-five per cent, but if they were made to the Insurance Committees they would have to have been one hundred per cent. Since this time the arrangements for the financing of health education have been an arena for political bargaining. It was also significant that from the beginning the educational aspects of a public health campaign should have been excluded from the usual budgeting arrangements of public health services, and be separated from the other financing of health services through Insurance Committees. ${ }^{31}$ Since the sums involved, when

and the society was not officially convened until March 1916 . Hence there is a reference in paragraph 225 of the conclusions of the Royal Commission which specifically mentions the NCCVD as the agency which should give its imprimatur to the distribution of health education and propaganda materials.

30 'The report of the Royal Commission on Venereal Diseases', Br. med. J., 1916, i: 385-387.

31 The local insurance committees continued their position regarding health education and propaganda through to 1946. A memorandum from Robinson (permanent secretary to the Ministry) to the Minister (26.7.32) highlights this: "Insurance committees as a separate institution are an old story and owed their origin and in particular their anomalous powers in regard to health education and propaganda to $\mathrm{Mr}$. Lloyd George's well known antagonism to the Local Government Board and all its works. They are in fact a waste of money and we induced the Royal Commission of 1926-27 to recommend their abolition and replacement by the Health Committees of the counties and county boroughs. But the approved societies have a majority in the Insurance Committees and resisted the abolition backed by the doctors who do not fancy coming under a health committee which is apt to resist co-option of non-elected members. The local authority men would not play because the money is Local Health Insurance Fund money and they held it wrong in principle that a committee of a Local Authority should have responsibility without Rate Interest. Between them they were too much for us so we had to go on as we were." (Ref: PRO.MH55/2). 


\section{Venereal disease and the prophylaxis dilemma 1916-1926}

totalled across the country, were far from small it was a sizeable budget for an independent and publicly unaccountable society to handle. 32

The NCCVD managed to ensure through deputations to Long that they would receive not only financial backing but also government endorsement for their policy. These meetings took place before the NCCVD had produced any clear or recognizable policy or programme, it was in effect a blank cheque of support that they gained at this stage. This remarkable success may be attributable to the fact that the Board was simply over-burdened with the administrative problems of setting up the new venereal disease centres and co-ordinating them with existing treatment schemes. When the irate Medical Officer of Health of York wrote to Newsholme in November 1916 protesting that the Board had not provided any educational or propaganda circulars and posters for the Local Authorities to use, Newsholme quickly spotted an opportunity to hand this work over to the NCCVD. ${ }^{33}$ Long seemed to be in a great hurry to implement the new treatment schemes and brooked no criticism of the new regulations that the department issued. One consequence of this haste was that the British Medical Association were decidedly annoyed that they were not given time to submit their own analysis of the new treatment and propaganda schemes. ${ }^{34}$

At their second annual conference the NCCVD were able to report considerable expansion of their activities; they had developed an identifiable programme of leaflets, lectures, posters promoting early treatment for venereal disease, and the free diagnosis clinics. They had also secured official recognition for the establishment of some fourteen branches of the organization, and were engaged in international tours and "fact finding" expeditions. A message from the King was sent to the conference expressing congratulations on the work of the Council. This royal message was quoted ritualistically at every subsequent conference. They took a guarded position with regard to prophylaxis, finding it: ". . . Undesirable for the Council to take steps in the direction of a campaign in favour of prophylactic teaching . . . unwise for the Council to go further than the Royal Commission. A distinction can be drawn between prophylaxis and early treatment . ..".35

For the duration of the war the majority of the NCCVD's work was concentrated upon the civilian population but they quickly saw an area for expansion with the coming of demobilization; they were therefore highly active in publicizing the possible effect of demobilization on the incidence of venereal disease. In response to this pressure the Local Government Board issued V.D. Circular 19 calling upon all local authorities to establish treatment centres in every town with a population of over 20,000 and to appoint full-time venereal disease officers. Venereal disease was therefore made a priority area for public health education and yet there was still a strong resistance to promoting any form of self-disinfection as either treatment or

\footnotetext{
32 From 1918-1929 the NCCVD had a minimum annual government grant of $£ 10,000$, and some years it rose to $£ 15,000$. (NCCVD Minutes). According to Harley Williams (A century of public health in Britain, London, 1932) the sum in 1916 was $£ 16,250$ and it was something of a precedent in that it was the first time the Treasury had paid a grant to a private organization for propaganda purposes.

33 PRO/MH55/534. Medical Officer of Health (York) letter to Newsholme, 9 November 1916.

34 Br. med. J., 1916, ii: 266-267.

35 Annual Report of NCCVD, 1916.
} 
prophylaxis. The NCCVD's policy on prophylaxis hardened into one of complete opposition reflecting what they judged was a moral and political consensus. The moral argument held that prophylaxis only served to legitimize "irregular" and promiscuous sex and thus actively promoted immorality by removing the natural penalties associated with promiscuity. A Ministry of Health interdepartmental committee, reporting in 1919, stressed the political opposition in its statement that the issuing of "packets for self-disinfection" was neither desirable nor practicable and that the priority should be given to early treatment and moral teaching.

It was probably the expansion of the services for treating venereal disease which drew attention increasingly to the inadequacies of the promotional and educational policy of the NCCVD. The expansion led the NCCVD to increase its recruitment of lecturers and staff officers, and these came mainly from the military after demobilization where they had had experience with both treatment and prevention techniques based on "packets". They were therefore severely critical of the failure of the NCCVD to legitimize this system or any other simple prophylactic measure. Wansey Bayly, the Secretary to the SPVD, recounts in his memoirs that his first work after demobilization was with the NCCVD as a lecturer: "To my surprise, I found all reference to disinfection was taboo, and that employment as a lecturer was conditional on agreement not to mention or recommend personal disinfection as a method of combatting venereal disease." 36

The NCCVD's policy was reinforced by the quite strict legal restrictions embodied in the 1917 venereal disease legislation which made it an offence to advertise remedies for diseases arising from sexual intercourse. There were sporadic prosecutions under Section I of the Act and penalties ranged from $£ 200$ fines in Newcastle to six months' imprisonment in Scotland. The net effect of this was that local authorities were unwilling to risk prosecution by allowing their employees or their agents to promote self-disinfection for use as a cure for venereal disease or as a prevention against it. Ironically enough, it was as a result of pressure from the British Medical Association that the government had become involved in regulating advertising in this field. 37

\section{CONFLICT AND THE FOUNDATION OF THE SOCIETY FOR THE PREVENTION OF VENEREAL DISEASE (SPVD)}

During 1919 and 1920 a significant number of doctors, particularly ex-army doctors, voiced their criticisms of the NCCVD in the popular press and in medical journals. The British Medical Journal became a regular forum for the debate on prophylaxis, along with the letters page of The Times. In October 1919 the Society for the Prevention of Venereal Disease (SPVD) was formed under the chairmanship of Lord Willoughby de Broke, its aim being to promote the dissemination of knowledge of the prevention of venereal disease, i.e. to promote the prohibited "packet system". They gave short shrift to the morality arguments of the NCCVD with some hard-nosed realism: ". . . Human nature being what it is, we cannot enforce sexual continence why then should

36 H. Wansey Bayly, Triple challenge: war, whirligigs and windmills, London, Hutchinson, [n.d.].

37 A. Fessler, 'Advertisments in the treatment of V.D. and the social history of V.D.', Br. J. vener. Dis. . 1949, 25. 


\section{Venereal disease and the prophylaxis dilemma 1916-1926}

we not do our utmost to minimise the evil results which do often follow from sexual irregularity . . ."38 The SPVD were quite explicit about the kind of propaganda and packet system they wanted to promote, they suggested that notices should be placed in all public lavatories to the effect: “. . . Every time you have sexual intercourse with a woman who is not your wife you run the risk of venereal disease. You can avoid disease in one way. In every public water closet is an automatic machine, by putting a penny in the slot you will obtain a packet with the necessary material. Apply them according to the instructions and you will be safe . . ." ${ }^{39}$ Local authorities were to provide these packets which were to be made up of potassium permanganate and calomel ointment.

Throughout 1920 the SPVD stepped up its campaign in the press against the NCCVD, and was particularly successful in recruiting Dr. Wilson, the medical correspondent to The Times, as a member of the Society. The lobbying of Willoughby in the House of Lords was also instrumental in gaining the support of the press barons, Northcliffe and Burnham, and the Editor of the Morning Post, who was invited to become President of the Society. The campaign was not merely critical of the ineffectiveness of the NCCVD but mounted a case for taking over its government grant and abolishing the 1917 V.D. Act; this led it increasingly to focus its criticism upon the government. With the majority of the press, the medical journals, and sizeable factions in Parliament defending the SPVD policy of prophylaxis, it was an extraordinarily entrenched position that the Ministry of Health took.

By 1920 George Newman (Chief Medical Officer at the Ministry of Health) appears to have acknowledged the shortcomings of the NCCVD despite his own commitment to them. Newman as Medical Officer of Health from 1919-1939, and Arthur Robinson as permanent Secretary at the Ministry from 1920-1935, together favoured the moral philosophy of the NCCVD, a patronage that they clearly acknowledged in their departmental correspondence. Together they established a departmental orthodoxy on health education in this field that seemed impregnable and must in part account for the endurance of the NCCVD.

At the beginning of 1920, Addison, then Minister of Health, was beginning to lack confidence in the propaganda of the NCCVD and was contemplating shifting policy towards the SPVD to favour the packet system. Newman in a position paper outlined the problem with a frank recognition: ". . . There can be little doubt that early disinfection is for men practicable and effective, the question is not of scientific fact but social and administrative practice . . ."40

$\mathrm{He}$ argued that the endorsement of a packet system would be seen as the Ministry encouraging illicit sex, yet on the other hand he acknowledged that: "We must either put into the hands of persons themselves some means of treating themselves or provide proper places for people to be disinfected." 41 The ministerial response was to cool the issue and another interdepartmental committee was commissioned to review the prevalence of venereal disease and the effectiveness of treatment. Addison was at this time also generally questioning the policy of sponsoring voluntary bodies to provide

38 A. C. Magian, letter to Br. med J., 1919, ii: 797.

39 E. T. Burke, letter to ibid., 1919, ii: 509.

40 PRO. MH55/179. Chief Medical Officer to Secretary to Minister 1920.

41 Ibid. 
health propaganda; he wanted to look at the whole field of health propaganda since he felt there was a great deal of waste of money in administrative costs. ${ }^{42}$ In 1920 the Ministry of Health seriously considered the possibility of creating a separate branch of the department to take control of propaganda; however Addison was personally opposed to the department undertaking any form of popular propaganda work which in his eyes would be directed at the masses: ". . . it would be fatal if the Ministry of Health were to appear to be endeavouring to put the individual member of the population in leading strings." 43 After gingerly examining the possibilities of creating a small publicity and propaganda section to cover health and housing issues, Addison finally rejected the plans on the grounds that the Cabinet had a commitment to making economies in the field of publicity and although the Ministry of Health had a good case for sustaining a propaganda budget it was not prudent to argue the point. 44

Newman had persistently defended the work of the NCCVD during these discussions and even went so far as to claim that the Ministry would be incapable of doing the work themselves. It must be noted that the Ministry had to find only seventyfive per cent of the costs of the propaganda work, the remainder being found by the local authorities; whereas it was responsible for one hundred per cent of the costs of the venereal disease treatment and diagnosis centres. It is extremely difficult in retrospect to make a calculation of the differential costs to the Ministry. Strangely there do not appear to have been any hard calculations submitted to buttress either policy; this was avoided by each side focusing the debate on questions of efficacy of method rather than on costs. Any discussion of the element of costs accruing to the Ministry seemed to run up against Robinson's clear and total opposition to the SPVD policy on any grounds. 45

Since the Ministry was not going to develop any alternative policy of its own, Newman was despatched to have unofficial meetings with representatives from both societies. At this time it became clear that there was increasing dissatisfaction within the NCCVD itself and in July 1920 six senior members of the executive committee, all doctors, resigned to join the SPVD as a protest against the NCCVD attitudes towards prophylaxis and its failure to make any scientific enquiries into venereal disease. This was a serious blow to the NCCVD and Newman was obliged to remark to the Minister that most of the NCCVD "were impossible people", and that: ". . . I am not without hope that on some basis I can bring a little nearer together the quarrelling doctors though I cannot hope to do the same with the Bishops and the Ladies . . ."46

Addison, Newman, and Robinson refused to accept any formal deputations from the SPVD, hoping instead to forge an alliance between them informally and so to dampen the hostility. But it was their refusal to accept a delegation that spurred the SPVD to take their campaign into the press again, they also used their support in the -House of Lords to keep up a running sore of political and personal attack on Addison. The NCCVD was drawn into the public debate in the press, but the new president

42 PRO. MH55/27. 4 May 1920. Conference on propaganda.

43 PRO. MH55/27. 29 July 1920. Reconvened conference on propaganda.

44 Ibid.

45 PRO. MH55/179. February 1921. Note on L. A. draft leaflet.

46 PRO. MH55/179. Newman to Minister, 14 February 1921. 
(Lord Gorel) was more actively engaged in lobbying the Ministry; he wanted either unequivocal support in public or otherwise a commission to adjudicate between the two societies. Addision had a good personal relationship with Gorel, and although they met informally Gorel was told that he could publicly announce that the Minister had given his personal approval to the work of the NCCVD. 47

\section{THE MINISTRY OF HEALTH AS SPONSOR AND ADJUDICATOR}

A position paper to the Cabinet in 1921 made it clear that the Departmental policy was unmoved by the SPVD: “. . . if official recognition were given to the advocacy of self-disinfection for civilians, I think that it is certain that the moral sense of the community would be outraged and in my opinion it is doubtful whether we should be justified in taking any steps which might have this result even if medical opinion unanimously called for that particular measure . . ."48 The Minister was clear in a memo to Robinson that they had good grounds to fight the SPVD policy but "if we are ambiguous or take refuge in generalities we shall be accused of shilly-shallying". 49 However, on analysis the "good grounds" turned out to be merely a feeling that prophylaxis did not meet the "evil".

Newman was more sceptical of this stance and recognized that if the NCCVD were to continue to receive departmental endorsement then they would need to define their policy more clearly and that they would need official vindication. He was therefore in favour of Gorel's plan to have an official.committee to examine the conflict, a move which would also have abated criticism of the Department. Gorel was only enthusiastic to have the committee if it was not presided over by a doctor. Newman, with a similar concern for institutional bias, suggested the ideal committee would be the Consultancy Committee of the Ministry. His thinking was that a thorough reappraisal of propaganda and education from within the Ministry would allow it to escape from the commitment that they had towards the NCCVD as a result of the 1916 Commission and hence they "could start again not entirely afresh but without some of the embarrassing commitments under which we labour". 50 For this reason Newman was emphatic that the idea of an enquiry should be seen to come from the Department and not from the NCCVD. After Addison's resignation in April 1921, he was replaced by Sir Alfred Mond who was less sensitive to Newman's diplomacy and took the rather blunt approach that the matter was a medical one and therefore should be dealt with by a Consultancy Committee composed of doctors and that since its report would be confidential the government would not be embarrassed by it. However, when Lord Dawson was nominated as the chairman of the Consultancy Committee, Newman realized that this solution would satisfy no one, since Dawson was also President of the NCCVD.

Mond had little sympathy with the dispute, he admitted51 that he himself "had a secret sympathy with the scientific basis of the prevention doctrine, but could never

47 PRO. MH55/179. Minutes of meeting of Lord Gorel and Minister, 2 March 1921.

48 PRO. MH55/179. MacLahan to Cabinet, 9 March 1921.

49 PRO. MH55/179. Minister to Robinson, 20 April 1921.

50 PRO. MH55/181. Newman to Robinson, 5 December 1921.

51 PRO. MH55/181. Minutes of meeting of Robinson, Newman, Dawson, and Minister, 16 December 1921. 


\section{Bridget A. Towers}

withstand the opposition that would be aroused if he adopted it officially." $\mathrm{He}$ wondered if the time had arrived for taking a bold policy, but discounted it on the grounds that the SPVD had a perverted view of sex. Another "bold" policy he toyed with was the cutting off of the NCCVD's funds, but again rejected it on administrative grounds. He threatened the NCCVD that if there was any more public conflict the Cabinet would get sick of the whole issue and abandon all the venereal disease work. ${ }^{52}$

Newman managed to sell his plan of an independent Committee of Enquiry to the Minister and it was set up under Lord Trevethin. Although it was styled as a private committee it did receive Ministry funds and services for its functioning, its brief was officially "to consider and report upon the best medical measures for preventing V.D. in the civil community having regard to administrative practicalities as well as costs". It was in reality, though, an elaborate device to ensure that the two societies could meet in an adjudicated conference without committing the Ministry to any particular outcome. In the meantime the NCCVD had been given notice that its grant was to be reduced by $£ 1,000$ (from $£ 15,000$ ) for 1922 and that the following year the grant would be further cut by a third. The news of this was greeted by the SPVD as a clear indication that they were likely to receive the balance of the funds.

With a further change of Minister (N. Chamberlain) at the time when Trevethin delivered the committee's report, Newman had the chance to present its conclusions in the context of the Department's own orthodoxy. The Minister met the General Secretary of the NCCVD before the publication of the report's conclusions so that the NCCVD should have an informed and immediate press release on the report; no such similar arrangements were made with the SPVD.

The report did not solve any of the differences between the societies and its very ambiguity of findings allowed each to claim that it sanctioned their own policy. The key elements here are paragraphs 14 and 32; early disinfection was acknowledged as effective but rejected on the grounds as being the least effective basis for a venereal disease programme on costs grounds; disinfection was endorsed as part of a general treatment programme, not a preventive programme. Disinfectants were therefore allowed to be sold by chemists but not advertised.

Newman quickly spotted the ambiguity and advised the NCCVD to be most careful in endorsing the report. However, under the influence of The Times and the British Medical Journal the two societies accepted the report publicly and so put an end to what The Times called an "unedifying wrangle". It was a clear public papering-over of the division, and almost immediately the SPVD sought to enhance its position by petitioning for a grant equal to that given to the NCCVD. But on this matter Chamberlain was firm that no funds should be made available until there was clear evidence that the two societies were co-operating. The actual policy and programmes that such a joint venture might produce was never seriously considered by anyone; the prospective grant was only an incentive to publicly decorous behaviour.

The NCCVD, rather than defending its historic right to funds, went on aggressively to petition for additional funding in order to carry out the "new" propaganda work recommended by Trevethin, and forecast its expenditure at $£ 58,000$ for 1924.53

52 Ibid.

53 PRO. MH55/191. NCCVD letter to Minister, 11 December 1923. 


\section{Venereal disease and the prophylaxis dilemma 1916-1926}

Newman sustained the line of the Minister and refused to give any additional funds until there was cvidence of united work between the societies; but this holding of the funds did not secure unity as Wansey Bayly (Secretary to the SPVD) records in his memoirs, instead therc were inconclusive meetings whose minutes had constantly to be censored: ". . . During the discourses, it emerged that the NCCVD were not in reality free agents, or an independent organisation but were in effect the propaganda department of the M.O.H. in regard to V.D. One prominent member of the NCCVD said, 'We get $£ 7,000$ a year from the M.O.H. and if it comes to throwing over $£ 7,000$ or disinfection, we shall throw over disinfection'." 54

In July 1924 Sir Auckland Geddes took over the presidency of the SPVD, and it was hoped in Whitehall that he would manage to reconcile the two societies and preside over them both. Part of the deal involved a radical change by the NCCVD which was to endorse disinfection as prophylaxis, not just as treatment, and to embody this in their propaganda.

The NCCVD were naturally confused, since Geddes was presented to them as a president of whom the department approved although his own inclinations were contrary to the policies defended by the Ministry of Health. A memorandum from Newman to the Minister demonstrated the ambiguity of the NCCVD's position; he pointed out that the NCCVD wanted to change their policy in order to meet Geddes and so make the amalgamation of the two societies possible, but they were fearful that this would alienate them from the department. Newman himself provided no comfort, repeating the orthodoxy that the department would not pay for propaganda on disinfection. ${ }^{55}$ At the same time he noted with relief to the Minister (Chamberlain) that public interest in venereal disease as reflected in the press was declining, as was the incidence of it. His policy of manipulation for inaction and quietude was apparently successful. 56

The NCCVD solved its major problems of change of policy and presidency by a change of name, in 1925 it became the British Social Hygiene Council. Although it publicly claimed that it would not be any the less concerned with venereal disease, it was apparent that the society was interested in developing other areas of education and propaganda and hoped to attract further government support for this. The theme of social hygiene was also wide enough to include the co-option of many smaller associations and societies involved in health promotion and education. It was also a theme which appealed directly to the racist beliefs of many of the SPVD members, since the emphasis of the education programme was on the sponsorship of a racial conscience, and a "pride of race". 57 The themes of race and hygiene by 1925 had begun to replace class and morality as dominant values in health education. ${ }^{88}$ The BSHC

54 Bayly, op. cit., note 36 above.

55 PRO. MH55/191. Newman to Robinson, 23 January 1925.

56 PRO. MH55/191. CMO (Newman) memo to Minister, 2 February 1925.

57 C. J. Bond, 'British Social Hygiene Council', Br. med J. , 1925, ii: 88: "It is even more important to arouse in the minds of the people a racial conscience, a pride of race which will enable an enlightened public opinion to focus its attention."

58 The themes of race and hygiene during the 1920s and 1930s that dominated the international social hygiene movements require considerable explication and will be followed up in a sequel paper; some idea of this theme can be found in G. Harpham, 'Time running out: the Edwardian sense of cultural degeneration', Clio $V, 1976$, no. 3, pp. 283-301. The relationship of class and morality in health education historically is 
enjoyed a brief period of popularity and sponsorship from the Ministry of Health but eventually fell to the same internal politics which obliterated the SPVD, although that was in 1942 and by that time Newman had finally gone.

\section{SUMMARY}

The theme of prophylaxis in venereal disease policies much preoccupied the health educationalists and propagandists for the decade 1916-1926. It has often been characterized as a dispute between moralists and medics. However, it turns on a far more complicated division of interests. The early propagandists opposed any form of regulationist policies which were seen as a form of morals policing, an invasion of civil rights and discriminating unfairly against women. The military developed a policy that was a mixture of extreme laissez-faire and severe regulation, they were clearly opposed to any form of moral education which they saw as either useless or a serious threat to morale. Army doctors, taking their service experience into civilian life seriously questioned a policy which prevented them from using techniques which they knew to be effective. This situation brought into being the SPVD which in supporting the use of prophylactics challenged the educational approach, the orthodoxy supported by the NCCVD.

As the NCCVD became more intransigent, so the SPVD more openly defended prophylaxis as the priority venereal disease control. If some doctors were willing to defend the use of chemical treatments and to belittle the moral emphasis in much of the NCCVD propaganda, they were often less enthusiastic about sponsoring a system of self-medication which allowed the medical practitioner to be by-passed. The SPVD always had a lingering retinue of doctors who demanded that the disinfectant scheme should be operated with the involvement of doctors, and packets prescribed solely by practitioners. Doctors were keen that health educationalists and their propaganda should place the medical practitioner as the focal point in any campaign, and the field of venereal disease was seen as important in stimulating the development of the speciality of venereology. Doctors did not welcome the extension of self-referrals to local authority clinics, since that again diminished the role of the practitioner.

Sir B. Blackett, president of the BSHC, writing to Robinson in 1932 on the problems surrounding health education during the 1920s, pointed out that those who argued in favour of the individual always paying for his treatment and medical services did give credence to the accusation that the medical profession had a vested interest in disease which consciously or unconsciously obstructed progress in preventive medicine. He cited an example of this tendency from an article in the Lancet (4 June 1932) in which a doctor claimed that people were going to free venereal disease clinics when they could in fact afford to go privately, hence venereal specialists were losing out. That this quote cannot be seen as atypical is endorsed by a note made by Robinson on it; "it is here of course that progress on the preventive side finds a chief enemy". ${ }^{59}$ A reply in the Lancet of the next week went on to argue that a practitioner who devotes himself to new kinds

considered in the context of the Medical Department of the Board of Education by O. Musgrave, 'Morality and the Medical Department 1907-1974', Br. J. Educ: Stud., 1977, 25: no. 2.

59 PRO. MH55/2. Paper submitted by Blackett to Robinson, 4 July 1932, 'A layman's plea for a positive health policy'. 
of preventive work "finds himself under suspicion from his fellows who consciously or unconsciously feel their incomes threatened". 60

The Ministry of Health establishment wanted propaganda and educational services to be tailored to the existing administrative structure and did not want to become involved in any contentious issues about sexual mores, or create new precedents of selfdiagnosis or self-prescription. Many of the doctors in the Ministry of Health felt that if the government licensed self-medication it would be interposing itself between doctor and patient and infringing clinical judgment. On the other hand the Ministry of Health was concerned that this area of public health should be as efficient and economical as other sectors of the public health services. The NCCVD enjoyed a favoured style pressure group relationship with the government during this period and consolidated its position in a particular field of health education and propaganda to such an extent that it was able to expand into new and wider areas and receive substantial support long after its initial basis for organization had disappeared.

The SPVD on the other hand failed to compete successfully as a pressure group; it never managed to penetrate the Ministry of Health establishment, and it was severely handicapped by the combined hostility of the Chief Medical Officer and the permanent secretary to the Department. Despite its public campaign in the press and parliament it never secured the legitimacy of being a government-sanctioned educational agency and therefore never obtained guaranteed funds or access into the policy-making process at Whitehall.

60 PRO. MH55/2. Marginal note by Robinson on Blackett's paper. 